\title{
New Path of Media-based International Communication in Mobile APP under Computer Background
}

\author{
Zhengzhi Jia \\ English-Chinese Bilingual Broadcasting and Hosting Art,Communication University of Zhejiang, Hangzhou, \\ 310018, China \\ International Journalism and International Communication, Birmingham City University, B5 5JU,Birmingham,UK \\ Corresponding Author's Email:358385507@qq.com
}

\begin{abstract}
Under the background of world economic integration, China's economic exchanges with other countries in the world are becoming closely. As China's strength on the world stage to enhance, China's stain is becoming strong. In order to establish China's image and transmit China's voice, the construction of international strategic communication capacity has become the main goal and main way of China's public diplomacy. By using case analysis and literature research, this paper finds that in current practice, Chinese international communication, which mainly depends on mainstream media, has not achieved better communication results. Thus ignoring the power of multi-subject, China's international communication process cannot keep up with the trend of "media socialization" and affects the implementation of China's public diplomacy.
\end{abstract}

Keywords: Computers, media, international communications, mobile APP

\section{INTRODUCTION}

Along with the development of the new generation of internet technology, western countries are more inclined to use the international communication mode of media in the computer background, and with the expansion and deepening of china's external communication, the new path of media-based international communication on mobile phone APP has become an important path to shape china's image. At present, the Chinese government has begun to strengthen "international communication capacity building" to convey China's voice by creating "international first-class media ".

A new way of media-based international communication in mobile phone APP under computer background has attracted the interest of many experts and has been studied by many teams. For example, in "Research on the Application of Chinese Mobile phone ", Xiao Menggang took Chinese learners as the object, investigated the application status of network platform, computer system platform and mobile phone platform, and investigated and analyzed all kinds of applications of mobile phone platform[1].According to Ming
Anxiang, in order to change the current pattern of international news reports monopolized by the West, efforts must be made to cultivate and strengthen the main media of Chinese news reports, and the government must strengthen its policy tilt, such as "first disclosure of major news information, in-depth disclosure, priority interview China's main news media, establish the credibility and authority of China's main news media [2].Liu Xiaoying put forward the task of building our country's international first-class media. She believes that it is necessary to strengthen the construction of international first-class media from three aspects one is to change the concept of communication and enrich the content of communication; the other is to expand the international reporting network, strengthen global reporting and build professional news reporting teams; and the third is to establish an international communication system with equal emphasis on both cause and industry, while adhering to the principles of enterprises, appropriately increase the path of industrial development[3-4].Other teams have found that Chinese English websites are not mature in multimedia applications, multimedia reports are still deficient, and the powerful advantages of multimedia are far from 
being brought into play. Therefore, news networks are rich in reporting means from external reports, changing text reports to multimedia reports, and enhancing interactivity from one-way to multi-directional communication, such as setting up multiple modes of communication, using interactive news writing techniques, and providing news content subscription services[5].Focusing on the relationship between mass media and China's international education, Ji Guangrong discussed in detail the present situation and value of the application of newspapers, radio, television films and the Internet in China's international education, and looked forward to the prospect of mass media in China's international education[6]; based on the perspective of communication, $\mathrm{Hu}$ made a concrete analysis of the application of print media, electronic media, network media and mobile media in China's international education, and provided corresponding suggestions according to the different media's communication methods[7].Although their research results are very rich, there are still some shortcomings.

Through the analysis of this paper, it is found that different subjects have different roles and weights in the pattern of public diplomacy. As a highly intensive social organization with capital, knowledge, technology and talents, enterprises are an important node of the world economic network and one of the most active subjects in social, economic and cultural exchanges.

\section{METHOD}

\section{1. "Next Generation Internet"}

The Next Generation Internet uses powerful computers, servers and networks to provide a variety of services for business, education, culture, and entertainment. "Next Generation Internet" actually refers to Internet technology based on IPV6 protocols, compared with the protocol-centric IPV4 Internet developed in the 1980s, the next generation Internet has the advantages of faster, larger, safer, more timely, more convenient and more effective, and its huge capacity can provide IP, meanwhile, by adopting advanced wireless mobile communications technology, will implement "ubiquitous mobile internet and wireless communication applications ". According to CNNIC reports, Chinese Internet users have reached 3.1 billion, cell phone APP accounts for $95.1 \%$ of users, this indicates that, can spread individual opinions to every corner of the world. Therefore, in the context of the next generation of the Internet, how to participate in the reconstruction of the new international communication order, rationalizing the flow of information between developed and developing countries, this is not only an opportunity for China to enhance its global voice in international exchanges, it is also a major historical task facing China[8].

\subsection{Definition of International Communication}

International communication is a cross-cultural information exchange between countries or other international actors. International communication is related to national interests and has obvious political tendency and ideological color. International communication can be divided into broad sense and narrow sense: in a broad sense, international communication includes all diplomatic contacts between countries, such as summit visits, bilateral talks, inter-regional summits and other related matters. With the emergence of countries, extensive international communication activities have emerged; narrow international communication has emerged with the emergence and development of mass media and the gradual development of information globalization, such as the establishment of international radio stations and the transmission of radio programs to other countries[9].

\subsection{Participatory Media}

Participatory media is a two-way process in media production. One process is the traditional information transmission process dominated by the media, the other is the information production process, Which is dominated by the audience, or the other way around to the previous process. These two processes move in the opposite direction and merge with each other, bringing new development space for media production and media consumption. On the one hand, with the support of Internet technology, traditional media have opened up richer communication channels and created more sources of interest. On the other hand, the audience has mastered more and more media technology, put more content in their own control, and strive for more participation in media production. The integration of these two forces strengthens the relationship between media production and media consumption. In this sense, each audience may become a node in the media production network, and their interaction and mutual penetration with professional media constitute a dynamic and mobile participatory media production model[10].

\section{EXPERIMENT}

\subsection{Experimental Data Sources}

This paper selects the main enterprises as the research object, discusses the feasibility and sustainable development of enterprises as a new path of international exchange in China, and through the collection and analysis of data, this study can provide a new perspective and data for China's international communication capacity building and China's public diplomacy development path. 


\subsection{Experimental Design}

Literature research method: refers to the collection, identification, collation of literature, and through the study of literature to form a scientific understanding of facts; case analysis: select the main enterprises as the research object, through the study of its model, function, problems and challenges, analysis of its feasibility and sustainable development, on this basis, study the role of enterprises in China's international communication path.

\section{RESULT}

\subsection{Analysis of Research on Huawei Mobile Phones}

With the rise of Chinese brands, Huawei cell phones as one of the best brands, its academic and professional studies are also emerging, based on "Huawei mobile phone" as the title / keyword / theme, for the period 2013-2020 as the full text database (CNKI) of Chinese periodicals, 12500/1210/23175, the statistical results are shown in Figure 2(as of December 2020), demonstrated that Huawei mobile phone research has been valued by academia, warming up rapidly after 2016, as shown in Figure 1.

\section{Huawei mobile phone research results}

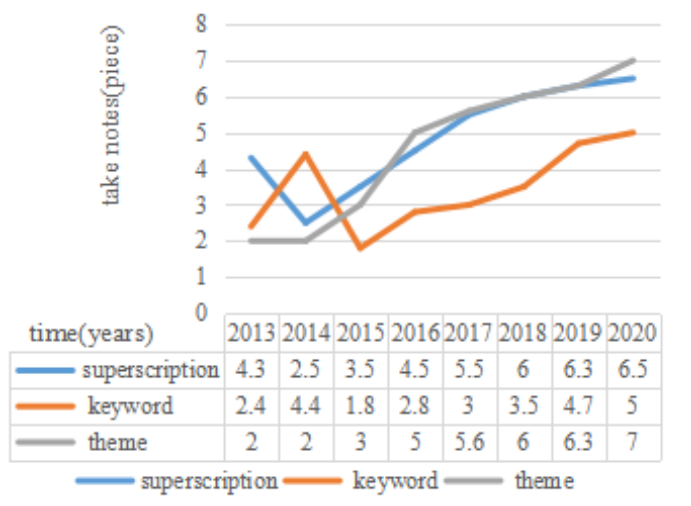

Figure 1. Trends in Huawei mobile phone research

To sum up, at the present stage, the academic and industry research on Huawei is mainly focused on its national strategy, cross-cultural communication, marketing strategy, corporate culture, internal management and other angles, basically no brand communication research specifically aimed at Huawei use from the media, which is also the main basis of this paper.

\subsection{Analysis of Internationalization of Markets}

The degree of market internationalization is an important index to measure the degree of enterprise internationalization, an important part of the process of promoting internationalization, and even an important purpose of the whole internationalization. Huawei mobile phone has been expanding overseas since 1996, reaching 49.8 million in 2016. Overseas sales doubled, Huawei reached 98 million in 2017 and 591 million in 2018 , accounting for $70 \%$ of total sales, as shown in Figure 2.

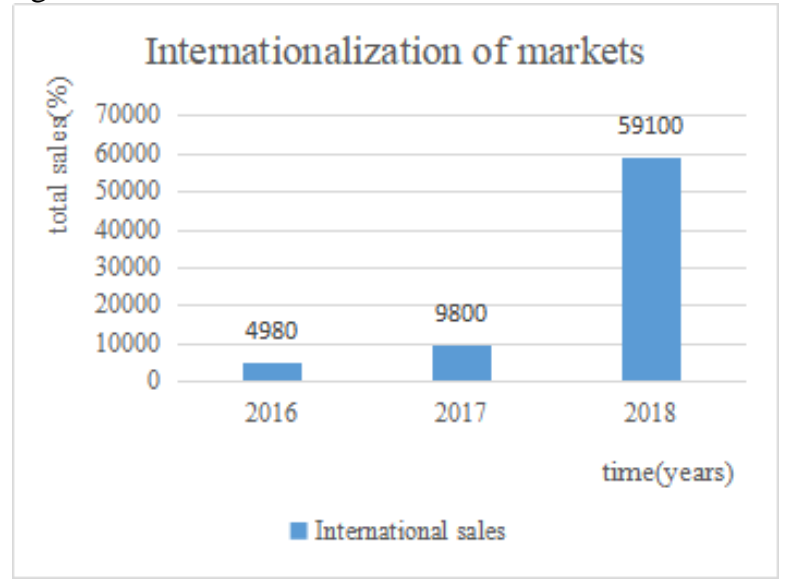

Figure 2. Internationalization of markets

As can be seen from Figure 2, a strong market system has been established Huawei all over the world, including 15 institutions and 35 joint innovation centers around the world. At the same time, promoting industrial innovation with partners, and internationalizing their own market partners and channels, also bring customers the final experience.

\subsection{Analysis from the Internationalization of $R$ \& $D$}

Huawei launched R \& D internationalization at the same time as market internationalization: set up joint laboratories with Western giants such as SUN and Qualcomm, so that Huawei company's products can apply the most advanced research results. The early strategic cooperation between Huawei mobile phone and world-renowned companies in $\mathrm{R} \& \mathrm{D}$ mainly includes technology introduction, key material components, technical standards and patent authorization. At present, Huawei mobile phone has more technology export rights and has begun to license their own advantage patents in various fields with western giants. At the same time, the transformation of this cooperation mode reflects the qualitative leap of Huawei mobile phone's independent R \& D ability and brings huge market benefits. On the other hand Huawei the internationalization of mobile phone $\mathrm{R} \& \mathrm{D}$, the establishment of R \& D institutions around the world, establishment of R \& D centers Huawei mobile phones in Stockholm, Bangalore, Moscow, Silicon Valley and Dallas, and the international location of $\mathrm{R} \& \mathrm{D}$ centers in the most developed countries and areas of communication and IT technology, such as Switzerland, Silicon Valley, to ensure that Huawei mobile phones are synchronized with the world in their fields, as shown in Table 1. 
Table 1. Internationalization of R \& D

\begin{tabular}{|c|c|}
\hline $\begin{array}{l}\text { Western peers or } \\
\text { suppliers }\end{array}$ & $\begin{array}{c}\text { SUN、Intel, Microsoft, Qualcomm, } \\
\text { Motorola }\end{array}$ \\
\hline $\begin{array}{l}\text { Strategic } \\
\text { cooperation }\end{array}$ & $\begin{array}{c}\text { Technology Introduction, Key Material } \\
\text { Components, Technical Standards and } \\
\text { Patent Licensing }\end{array}$ \\
\hline $\begin{array}{l}\text { Research and } \\
\text { development } \\
\text { center }\end{array}$ & $\begin{array}{c}\text { Stockholm, Dallas, Silicon Valley, } \\
\text { Bangalore and Moscow }\end{array}$ \\
\hline $\begin{array}{l}\text { International } \\
\text { location of R \& } \\
\text { D centres }\end{array}$ & Switzerland, Silicon Valley \\
\hline
\end{tabular}

Table 1 shows that since its establishment, Huawei mobile phone has emphasized independent R \& D and invested more than $11 \%$ of its annual sales in $\mathrm{R} \& \mathrm{D}$, not behind closed doors, but through an open win-win strategy for world-class partners, Huawei can quickly catch up with the world's advanced levels through strategic cooperation. In addition, in creating a more open R \& D system, Huawei launched an innovative research project (HIRP) to the world in March 2010 to guide ideas and methods in other areas and work together to solve cutting-edge science and technology problems.

\subsection{Analysis of Facebook APP}

Facebook APP was founded by Mark Zuckerberg, who dropped out of Harvard in February 2004, with two other students, at first, it's a local social platform for Harvard students to communicate, then the website quickly spread to Boston, ivy League and other famous universities. Facebook APP launched a Facebook platform, under the platform policy, an open "participatory system ", allowing third parties to convert Facebook APP albums, or direct applications based on Facebook APP platforms, users can install and use these APP software. Facebook APP provides individuals with an independent space to produce, accumulate, share and disseminate information. Facebook integrates many Web2.0 applications, Wiki, TAG, RSS, blog is a collection of 1 , in order to make communication more extensive, rich, efficient and vivid, it also provides convenient and rapid aggregation, help users find people who have something in common with themselves, as shown in Table 2.

Table 2. Facebook APP analysis

\begin{tabular}{|c|c|c|}
\hline & Advantage & Weakness \\
\hline $\begin{array}{c}\text { BBS of } \\
\text { Public } \\
\text { Forums }\end{array}$ & Open communication & $\begin{array}{c}\text { No private } \\
\text { space }\end{array}$ \\
\hline Blog & Totally personal & $\begin{array}{c}\text { Lack of } \\
\text { public space, } \\
\text { no } \\
\text { preservation }\end{array}$ \\
\hline
\end{tabular}

\begin{tabular}{|c|c|c|}
\hline Facebook & $\begin{array}{c}\text { Personal space and public } \\
\text { space, with personality } \\
\text { blog, convenient friends, } \\
\text { forum groups and other } \\
\text { functions, powerful } \\
\text { search function }\end{array}$ & \\
\hline
\end{tabular}

Table 2 shows that compared with public forum BBS, although BBS is famous for its open communication, it has no private space, posts go out and are no longer personal; compared with blogs, although completely personal, its deficiency is the lack of public space; compared with instant chat software, QQ groups, WeChat etc., its non-preservation is also a major weakness; Facebook APP combines personal space with public space, with personality blog, convenient friends, forum group and other functions, but also has a powerful search function, in March 2010, Facebook APP traffic exceeded Google traffic, become the world's largest website.

\section{CONCLUSION}

With the continuous improvement of comprehensive national strength, China has gradually become an important force in the world economy. However, with the continuous enhancement of China's strength, the voice of the western media on China's threat theory is becoming more and more high. Based on the present situation of China's international communication, this paper analyzes the common path of China's international communication, summarizes the difficulties faced by China's international communication, and puts forward a new path to undertake some international communication tasks through enterprises. It shows the important role of Chinese enterprises in international communication and looks forward to the challenges and opportunities faced by Chinese enterprises. At present, mobile APP is still in the development stage, and more and more media begin to use this form to carry out digital extension in their news field. However, the research on mobile news APP is relatively centralized, and the research space is very wide. We expect that future scholars can conduct more profound research in this field.

\section{REFERENCES}

[1] Wang Sha. Citing the report. Review of the English Test for International Communication - Examples of written communication tasks based on ETIC [J].]; and Overseas English ,2020,10(2):128-130.

[2] Xiang Y. International communication: continuity and change (3rd edition): by Daya Kishan Thussu, New York and London, Bloomsbury Academic, 2019, \$29.95 USD (paperback), 392 pp[J]. Chinese Journal of Communication, 2020,10(7):1-4. 
[3] Iio J, Wakabayashi S. Dialogbook: a proposal for simple e-portfolio system for international communication learning[J]. International Journal of Web Information Systems, 2020, 16(5):611-622.

[4] Ye X, Li M, He Q, et al. Impact of Canopies on Fire Spread in Pedestrian Streets[J]. International Core Journal of Engineering, 2020, 6(5):119-124.

[5] Merkulova L P, Kashina E G. Academics' Training for International Communication and Collaboration[J]. Vestnik of Samara University History pedagogics philology, 2020, 26(2):102-103.

[6] Chong C S. Successful international communication $[\mathrm{J}]$. Training Language and Culture, 2020, 4(1):55-65.

[7] A K G, B D I V, C V B, et al. Day-of-the-week effect and spread determinants: Some international evidence from equity markets - ScienceDirect[J]. International Review of Economics \& Finance, 2021, 71(10):268-288.

[8] Elsihar-Malka V, Ariel Y, Weimann G. Rethinking political communication in the digital sphere[J]. Journal of International Communication, 2020,7(2):1-21.

[9] Strenina M A. Digital economy: communication using neural networks in international communication[J]. RUDN Journal of Economics, 2020, 28(3):547-555.

[10] Suzina A C, Tufte T, César Jiménez-Martínez. Special issue: The legacy of Paulo Freire. Contemporary reflections on participatory communication and civil society development in Brazil and beyond[J]. International Communication Gazette, 2020, 82(5):174804852094368. 